\title{
Analysis of the Effect of Product Quality, Price Perception, Brand Image and Promotion on Customer Satisfaction to Achieve Repurchase Intention (Fiesta Chicken Nugget)
}

\author{
Theofilus Pirri, S.S \\ Master of Management Program \\ Mercu Buana University \\ Jakarta, Indonesia
}

\author{
Dr. Dipa Mulia, M.M., M.H. \\ Master of Management Program \\ Mercu Buana University \\ Jakarta, Indonesia
}

\begin{abstract}
This study aims to analyze the effect of product quality, price perception, brand image and promotion on customer satisfaction to achieve repurchase intention's Fiesta chicken Nugget in Jakarta, Indonesia. This study uses Non Probability Sampling and purposive sampling methods with a total of 190 respondents. Data analysis of this study is carried out by structural equation model (SEM) analysis using Lisrel 8.8.
\end{abstract}

The findings show that each independent variable namely product quality, price perception, brand image and promotion has a positive and significant influence on customer satisfaction as intervening variable. Customer satisfaction as intervening variable has a positive and significant influence on repurchase intention as dependent variable. The product quality has the biggest influence among the four independent variables on customer satisfaction. It is recommended that companies should focus on increasing the value of product quality and product price adjustments to increase customer satisfaction and the company should pay more intention to promotion and improve brand image for the better. Further research by conducting research on other variables with a larger sample is also recommended.

Keywords:- Product Quality, Price, Brand Image, Promotion, Customer Satisfaction, Repurchase Intention, Fiesta Chicken Nugget.

\section{INTRODUCTION}

Modern lifestyle with high-paced activities particularly in the urban communities make people prefer fast food restaurant. Some of the reasons why people are turn to fast food are they do not have time to cook, fast food is easy to get, and the environmental influence which also prefer fast food.

As the food industry develop, chicken nuggets have emerged as ready-to-cook package. Now people can buy them in supermarket. Serving the nuggets is pretty straightforward; customer simply need to fried them until they are cooked. Nuggets can be used as side dish. They are liked by various age groups from children to adult. This is because nuggets are nutricious and delicious. PT. Charoes Pokhphand Indonesia is the largest feedmil company in the country that has produced numerous processed chicken products such as Nugget Fiesta, Spicy Wing Fiesta, Fiesta Chicken Meatball, Champ Chicken Nugget, Okey Chicken Nugget, and many more. Fiesta Nugget currently controls $33 \%$ market share for the branded nuggets category. The largest market share is currently held by Champ, a brand that also owned by PT. Charoen Phokphand, which continously growing since it launched several years ago. As the food business in chicken nuggets category grow, the competition is getting tougher. Competitors products would offer more products with their respective advantages. Thus, the customer would have plenty of brand options to choose. Customer can to be more selective in choosing the products they eat.

Marketers are not only required to analyzed and understand the customer of their own products, but also the custormer of the competitors' brands and why they choose to buy them.

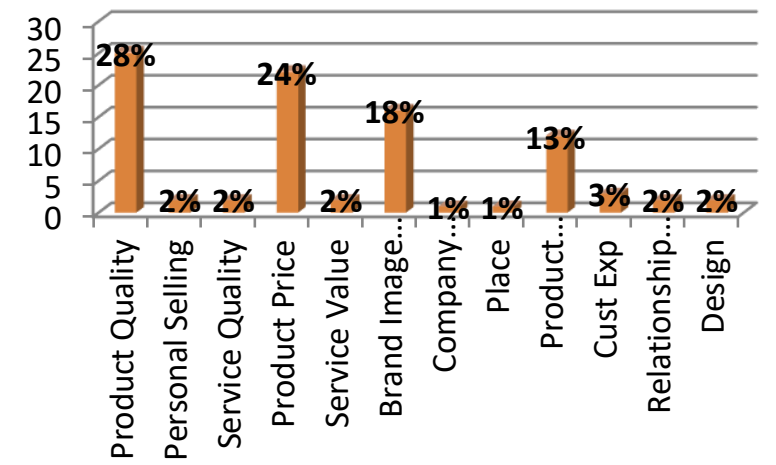

Fig 1:- Pre Survey Result

Based on the pre-survey result conducted by researches, the factor that affect the customer of chicken nugget is the quality of the product. The second factor is the price of Fiesta Chicken and the third is Fiesta brand image; Fiesta brand as processed food product is quite established. The last factor is promotion. According to Putri and Astuti ( 2017), customer satisfaction is positively and 
significantly affected repurchase intention. A customer who is satisfied with a certain product most likely will repurchase that product. So in the case of decreased sales and Top Brand Index of Fiesta Nugget, several factors will be discussed that might become company 's reference in getting the Fiesta product back on track that the company hopes for.

\section{LITERATURE REVIEW}

\section{A. Product Quality}

Standardization is needed to ensure the resulting products meet the predetermined standard so the customers do not lose their confidence in the product. According to Kotler and Armstrong (2018:283) product quality is "the ability of a product to demonstrate its function, including durability, realibility, accuracy, ease of opeartion and product repair, and other product attibutes". In strategic definition, "quality is everything that able to meet the needs of customer.

\section{B. Price}

The value that must be spent by the customer to get goods or service. According to Kotler and Armstrong (2018:314) price is the amount of money charged for goods or service or the amount of value that the customer exchanged for the benefits of owning or using the goods or service. Customer who want to enjoy or use certain product must let go an amount of value that expected of the product. The price of a product depends on manufactur and the value contained in the product. Price is pivotal part for a company revenue for the sustainability of the company.

\section{Brand Image}

Brand association has certain level of power and will get stronger as the consumption and the spread of information increase, and will go further if supported by other network. Brand image plays an important role in costumer behaviour in choosing which product to buy. Brand image includes product understanding and confidence in brand attributes (cognitive aspects), consequence of brand usage and suitable condition usage, also evaluation, feeling and emotion perceived with the brand (affective aspects). In the process of brand image developing it must be noted that stong brand has distinct identity.

\section{Promotion}

Company use promotion to introduce products to larger audience in order to increase the product awareness. According to Kotler and Armstrong (2018:76) "Promotion means activities that communicate the merits of the product and persuade target customers to buy it." It also use to inform the benefits and advantages of a product. Promotion is a tool used to define a product, to encourage and persuade potential customer in purchasing decision process. It is a way of communicating between buyer and seller about the existence of a product or service so it can influence attitude and behavious of potential customer in market, thus a promotion must be designed as appealing as possible with simple but informative message.

\section{E. Customer Satisfaction}

Company targeting the satified customer on the basis of the products they have placed in the market. Customer satisfaction is vital for marketer because it is a significantly positive effect in long term, such as repurchase and customer loyalty.According to Kotler and Keller( (2016:138) definiton, "Satisfaction is a person'd feeling of pleasure or disappointment resulting from comparing perceived product's performance (or outcome) in relation to their expectations. If the performance does not meet expectations, they will not satisfied."

Overall, customer satisfaction has three antecedents: preceived quality, perceived value, and customer expectations. In general, the latter is prediction of consumer belief of what will they get if they buy or consume product/service. Meanwhile, perceived performance is the customer impression after they consume the product they have bought. If the customer is satisfied the company's goal will achieved because its products is valuable for customer.

\section{F. Repurchase Intention}

Satisfaction gained by a customer can motivate someone to make repeat purchases and become loyal to the product or to the store where he bought the item so he can tell good things about the product to other people. High repurchase intention reflects consumer high satisfaction when he decided to adopt a product. The decision to embrace or reject a product is determined after the customer try it and he will decide whether he like it or not. The prefence for the product take place if the customer perceives that they get good quality item and can fulfill or even exceed his whishes and expectations. In other words, the product is considered high value by the customer. High repurchase intention will have positive impact on the product success in the market.

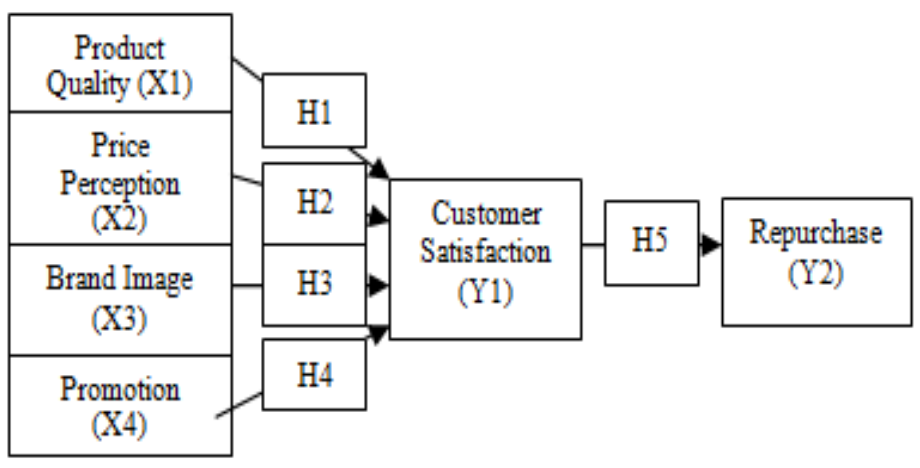

Fig 2:- Research Model

Hypothesis:

$\mathrm{H} 1=$ Product Quality (X1) has positive and significant effect on customer satisfaction

$\mathrm{H} 2=$ Price Perception (X2) has positive and significant effect on customer satisfaction

(Y1) 
$\mathrm{H} 3=$ Brand Image $(\mathrm{X} 3)$ has positive and significant effect on customer satisfaction

(Y1)

$\mathrm{H} 4=$ Promotion (X4) has positive and significant effect on customer satisfaction

(Y1)

$\mathrm{H} 5=$ Customer Satisfaction (Y1) has positive and significant effect on Repurchase Intention (Y2)

\section{RESEARCH METHODOLOGY}

Survey research by collecting data from respondents using questionnaire. Independent variables in this research are Product Quality (X1), Price Perception (X2), Brand Image (X3) and Promotion (X4). Dependent variable is Repurchase Intentiom (Y2) and intervening variable is Customer Satisfaction (Y1). This study use Likert Scale with SEM method. Samples for this sudy are the people from DKI Jakarta Province with total sample of 190.

\section{STUDY RESULT}

This study aimed to determine the effect of product quality, price, brand image, and promotion on customer satisfaction to achieve repuchase intention of Fiesta Chicken Nugget product. Research data that have been collected were analyzed descriptively and quantitatively.

Descriptive analysis was carried out with Microsoft Excel program to assess product quality, price, brand image, promotion, customer satisfaction, and repurchase intention whereas quantitative analysis conducted with stuctural equation mode - SEM and use LISREL 8.8 software to figure out the impact of product quality, price, brand image, and promotion on customer satisfaction to achieve repurchase intention. The following are the characteristic of respondents.

Respondents of this study were dominated by women as much as $63.61 \%$, and in terms of age, 31-40 years old is at $51 \%$. From the educational side, majority of the respondents are high scholl graduates at $51.58 \%$ and majority income group of 3-5 million at $55.26 \%$.

\section{A. Analysis Result and Discussion}

Hypothesis testing in this study is done with structural equation model (SEM) with measurement analysis method of confirmatory factor analysis (CFA) in the initial stage using LISREL 8.8 program.

\section{$>$ Confirmatory Model Measurement Analysis \\ - SEM Validity and Reliability Testing \\ $\checkmark$ CFA Product Quality Variable (XI)}

\begin{tabular}{|c|c|c|c|c|c|c|}
\hline \multirow{2}{*}{$\begin{array}{c}\text { Indicator } \\
\text { Code }\end{array}$} & \multirow[b]{2}{*}{ SLF } & \multirow{2}{*}{$\begin{array}{c}\text { Standard } \\
\text { Errors }\end{array}$} & \multirow[b]{2}{*}{$e^{2}$} & \multicolumn{2}{|c|}{ Reliability } & \multirow[b]{2}{*}{ Validity } \\
\hline & & & & $\begin{array}{l}\text { CR } \\
\geq \frac{7}{70}\end{array}$ & $\begin{array}{l}\mathrm{VE} \\
\geq \\
0,5\end{array}$ & \\
\hline PQ1 & 0.91 & 0.12 & 0.01 & \multirow{6}{*}{0.98} & \multirow{6}{*}{0.91} & Valid \\
\hline PQ1 & 0.91 & 0.12 & 0.01 & & & Valid \\
\hline PQ1 & 0.99 & 0.01 & 0.00 & & & Valid \\
\hline PQ1 & 0.96 & 0.06 & 0.00 & & & Valid \\
\hline PQ1 & 0.92 & 0.12 & 0.01 & & & Valid \\
\hline PQ1 & 0.91 & 0.11 & 0.01 & & & Valid \\
\hline
\end{tabular}

Table 1:- Result of Validity and Reliability Testing for Product Quality Variable (X1)

Source: Lisrel Output Researcher Processsing Result (2020)

Table 1 above showed there are 6 observed variable indicators in latent variable of Product Quality (X1) that have passed validity test, since all 6 indicators' loading factor value $\geq 0.50$. Whereas reliability test result of Product Quality (X1) showed good reliability value where Construct Reliabilty $(\mathrm{CR})=0.98>0.7$ and value of Variance Extracted (VE) is $0.91>0.50$.

$\checkmark$ CFA Price Variable (X2)

\begin{tabular}{|c|c|c|c|c|c|c|}
\hline \multirow[b]{2}{*}{$\begin{array}{l}\text { Indicator } \\
\text { Code }\end{array}$} & \multirow[b]{2}{*}{ SLF } & \multirow[b]{2}{*}{$\begin{array}{c}\text { Standard } \\
\text { Errors }\end{array}$} & \multirow[b]{2}{*}{$e^{2}$} & \multicolumn{2}{|c|}{ Reliability } & \multirow[b]{2}{*}{ Validity } \\
\hline & & & & $\begin{array}{c}\mathrm{CR} \\
\geq \overline{70}\end{array}$ & $\begin{array}{c}\mathrm{VE} \\
\geq \\
0,5\end{array}$ & \\
\hline PP1 & 0.88 & 0.17 & 0.03 & \multirow{6}{*}{0.98} & \multirow{6}{*}{0.88} & Valid \\
\hline PP2 & 0.88 & 0.17 & 0.03 & & & Valid \\
\hline PP3 & 0.91 & 0.13 & 0.02 & & & Valid \\
\hline PP4 & 0.97 & 0.05 & 0.00 & & & Valid \\
\hline PP5 & 0.94 & 0.08 & 0.01 & & & Valid \\
\hline PP6 & 0.94 & 0.08 & 0.01 & & & Valid \\
\hline
\end{tabular}

Table 2:- Result of Validity and Reliability Testing for Price Variable (X2)

Source: Lisrel Output Researcher Processsing Result (2020)

The table above showed there are 6 observed variable indicators in latent variable of Product Price (X2) that have passed validity test, since all 6 indicators' loading factor value $\geq 0.50$. Whereas reliability test result of Product Price (X2) showed good reliability value where Construct Reliabilty $(\mathrm{CR})=0.98>0.7$ and value of Variance Extracted (VE) is $0.88>0.50$. Therefore the latent variable Product Price (X2) has met the validity and reliablity test requirements. 
CFA Brand Image Variable (X3)

\begin{tabular}{|c|c|c|c|c|c|c|}
\hline \multirow[b]{2}{*}{$\begin{array}{c}\text { Indicator } \\
\text { Code }\end{array}$} & \multirow[b]{2}{*}{ SLF } & \multirow[b]{2}{*}{$\begin{array}{c}\text { Standard } \\
\text { Errors }\end{array}$} & \multirow[b]{2}{*}{$e^{2}$} & \multicolumn{2}{|c|}{ Reliability } & \multirow[b]{2}{*}{ Validity } \\
\hline & & & & $\begin{array}{l}\mathrm{CR} \\
\geq \\
0,70\end{array}$ & $\begin{array}{c}\mathrm{VE} \\
\geq \\
0,5\end{array}$ & \\
\hline BI1 & 0.88 & 0.16 & 0.03 & \multirow{6}{*}{0.98} & \multirow{6}{*}{0.90} & Valid \\
\hline $\mathrm{BI} 2$ & 0.90 & 0.15 & 0.02 & & & Valid \\
\hline BI3 & 0.97 & 0.04 & 0.00 & & & Valid \\
\hline BI4 & 0.93 & 0.08 & 0.01 & & & Valid \\
\hline BI5 & 0.96 & 0.05 & 0.00 & & & Valid \\
\hline BI6 & 0.93 & 0.09 & 0.01 & & & Valid \\
\hline
\end{tabular}

Table 3:- Result of Validity and Reliability Testing for Brand Image Variable (X3)

Source: Lisrel Output Researcher Processsing Result (2020)

Table 3 above showed there are 6 observed variable indicators in latent variable of Brand Image Variable (X3) that have passed validity test, because of 9 variable indicators present, all loading factor value $\geq 0.50$. Whereas reliability test result of Brand Image Variable (X3) showed good reliability value where Construct Reliabilty $(\mathrm{CR})=$ $0.98>0.7$ and value of Variance Extracted (VE) is $0.90>$ 0.50 .

\section{$\checkmark$ CFA Promotion Variable (X4)}

\begin{tabular}{|c|c|c|c|c|c|c|}
\hline \multirow{2}{*}{$\begin{array}{c}\text { Indicator } \\
\text { Code }\end{array}$} & \multirow[b]{2}{*}{ SLF } & \multirow{2}{*}{$\begin{array}{c}\text { Standard } \\
\text { Errors }\end{array}$} & \multirow[b]{2}{*}{$e^{2}$} & \multicolumn{2}{|c|}{ Reliability } & \multirow[b]{2}{*}{ Validity } \\
\hline & & & & $\begin{array}{l}\text { CR } \\
\geq \\
0,70\end{array}$ & $\begin{array}{c}\mathrm{VE} \\
\geq \\
0,5\end{array}$ & \\
\hline P1 & 0.95 & 0.07 & 0.00 & \multirow{6}{*}{0.98} & \multirow{6}{*}{0.89} & Valid \\
\hline $\mathrm{P} 2$ & 0.89 & 0.13 & 0.02 & & & Valid \\
\hline P3 & 0.91 & 0.13 & 0.02 & & & Valid \\
\hline P4 & 0.94 & 0.08 & 0.01 & & & Valid \\
\hline P5 & 0.94 & 0.09 & 0.01 & & & Valid \\
\hline P6 & 0.91 & 0.11 & 0.01 & & & Valid \\
\hline
\end{tabular}

Table 4:- Result of Validity and Reliability Testing for Promotion Variable (X4)

Source: Lisrel Output Researcher Processsing Result (2020)

The table above showed there are 6 observed variable indicators in latent variable of Promotion Variable (X4) that have passed validity test, because of 6 variable indicators present, all loading factor value $\geq 0.50$. Whereas reliability test result of Promotion Variable (X4) showed good reliability value where Construct Reliabilty $(\mathrm{CR})=$ $0.98>0.7$ and value of Variance Extracted (VE) is $0.89>$ 0.50 .
CFA Customer Satisfaction Variable (Y1)

\begin{tabular}{|c|c|c|c|c|c|c|}
\hline \multirow[b]{2}{*}{$\begin{array}{c}\text { Indicator } \\
\text { Code }\end{array}$} & \multirow[b]{2}{*}{ SLF } & \multirow[b]{2}{*}{$\begin{array}{c}\text { Standard } \\
\text { Errors }\end{array}$} & \multirow[b]{2}{*}{$e^{2}$} & \multicolumn{2}{|c|}{ Reliability } & \multirow[b]{2}{*}{ Validity } \\
\hline & & & & $\begin{array}{l}\mathrm{CR} \\
\geq \\
0,70\end{array}$ & $\begin{array}{c}\mathrm{VE} \\
\geq \\
0,5\end{array}$ & \\
\hline CS1 & 0.96 & 0.06 & 0.00 & \multirow{6}{*}{0.98} & \multirow{6}{*}{0.91} & Valid \\
\hline CS2 & 0.94 & 0.09 & 0.01 & & & Valid \\
\hline CS3 & 0.90 & 0.13 & 0.02 & & & Valid \\
\hline CS4 & 0.99 & 0.02 & 0.00 & & & Valid \\
\hline CS5 & 0.94 & 0.08 & 0.01 & & & Valid \\
\hline CS6 & 0.88 & 0.15 & 0.02 & & & Valid \\
\hline
\end{tabular}

Table 5:- Result of Validity and Reliability Testing for Customer Satisfaction Variable (Y1)

Source: Lisrel Output Researcher Processsing Result (2020)

The table above shows there are 6 observed variable indicators in latent variable of Customer Satisfaction Variable (Y1) that have passed validity test, because of 6 variable indicators present, all loading factor value $\geq 0.50$. Whereas reliability test result of Customer Satisfaction Variable (Y1) showed good reliability value where Construct Reliabilty $(\mathrm{CR})=0.98>0.7$ and value of Variance Extracted (VE) is $0.91>0.50$.

$\checkmark$ CFA Repurchase Intention Variable (Y2)

\begin{tabular}{|c|c|c|c|c|c|c|}
\hline \multirow[b]{2}{*}{$\begin{array}{l}\text { Indicator } \\
\text { Code }\end{array}$} & \multirow[b]{2}{*}{ SLF } & \multirow[b]{2}{*}{$\begin{array}{c}\text { Standard } \\
\text { Errors }\end{array}$} & \multirow[b]{2}{*}{$\mathrm{e}^{2}$} & \multicolumn{2}{|c|}{ Reliability } & \multirow[b]{2}{*}{ Validity } \\
\hline & & & & $\begin{array}{c}\text { CR } \\
\geq \\
0,70\end{array}$ & $\begin{array}{c}\mathrm{VE} \\
\geq \\
0,5\end{array}$ & \\
\hline RI1 & 0.99 & 0.01 & 0.00 & \multirow{8}{*}{0.98} & \multirow{8}{*}{0.87} & Valid \\
\hline RI2 & 0.83 & 0.24 & 0.06 & & & Valid \\
\hline RI3 & 0.87 & 0.18 & 0.03 & & & Valid \\
\hline RI4 & 0.90 & 0.14 & 0.02 & & & Valid \\
\hline RI5 & 0.90 & 0.14 & 0.02 & & & Valid \\
\hline RI6 & 1.00 & 0.00 & 0.00 & & & Valid \\
\hline RI7 & 0.83 & 0.24 & 0.06 & & & Valid \\
\hline RI8 & 0.99 & 0.01 & 0.00 & & & Valid \\
\hline
\end{tabular}

Table 6:- Result of Validity and Reliability Testing for Repurchase Intention Variable

Source: Lisrel Output Researcher Processsing Result (2020)

Table 6 above showed that there are 8 observed variable indicators in latent variable of Repurchase Intention Variable (Y2) that have passed validity test, because of 8 variable indicators present, all loading factor value $\geq 0.50$. Whereas reliability test result of Repurchase Intention Variable (Y2) showed good reliability value where Construct Reliabilty $(\mathrm{CR})=0.98>0.7$ and value of Variance Extracted (VE) is $0.87>0.50$. 


\section{Normality Analysis}

Test of Univariate Normality for Continuous variables

skewness

Kurtosis

skewness and Kurtosis

variable z-score p-Value

$\begin{array}{rrr}\text { PQ1 } & -0.006 & 0.996 \\ \text { PQ2 } & -0.046 & 0.964 \\ \text { PQ3 } & -0.184 & 0.854 \\ \text { PQ4 } & -0.448 & 0.654 \\ \text { PQ5 } & -0.384 & 0.701 \\ \text { PQ6 } & -0.479 & 0.632 \\ \text { PP1 } & -0.492 & 0.623 \\ \text { PP2 } & -0.534 & 0.593 \\ \text { PP3 } & -0.601 & 0.548 \\ \text { PP4 } & -0.784 & 0.433 \\ \text { PP5 } & -0.708 & 0.479 \\ \text { PP6 } & -0.854 & 0.393 \\ \text { BI1 } & 0.250 & 0.802 \\ \text { BI2 } & 0.126 & 0.900 \\ \text { BI3 } & -0.161 & 0.872 \\ \text { BI4 } & -0.457 & 0.648 \\ \text { BI5 } & -0.545 & 0.586 \\ \text { BI6 } & -0.714 & 0.475 \\ \text { P1 } & -0.210 & 0.834 \\ \text { P2 } & -0.159 & 0.874 \\ \text { P3 } & -0.190 & 0.849 \\ \text { P4 } & -0.197 & 0.844 \\ \text { P5 } & -0.466 & 0.641 \\ \text { P6 } & -0.366 & 0.715 \\ \text { C51 } & -0.285 & 0.775 \\ \text { C52 } & -0.267 & 0.790 \\ \text { C53 } & -0.396 & 0.692 \\ \text { C54 } & -0.592 & 0.554 \\ \text { C55 } & -0.919 & 0.358 \\ \text { C56 } & -0.922 & 0.356 \\ \text { R1 } & -0.995 & 0.320 \\ \text { R2 } & -0.305 & 0.760 \\ \text { R3 } & -0.376 & 0.707 \\ \text { R4 } & -0.819 & 0.413 \\ \text { R5 } & -0.795 & 0.427 \\ \text { R6 } & -0.972 & 0.331 \\ \text { R7 } & -0.218 & 0.828 \\ \text { R8 } & -0.995 & 0.320 \\ 15 & 1.179 & 0\end{array}$

Z-score p-value

$-0.081 \quad 0.935$

$\begin{array}{ll}-0.034 & 0.973 \\ -0.338 & 0.735\end{array}$

$\begin{array}{rr}-0.338 & 0.735 \\ -0.359 & 0.720\end{array}$

$-0.268-0.789$

$\begin{array}{ll}-0.268 & 0.789 \\ -0.097 & 0.923\end{array}$

$\begin{array}{ll}-0.097 & 0.923 \\ -0.496 & 0.620\end{array}$

$\begin{array}{ll}-0.496 & 0.620 \\ -0.399 & 0.690\end{array}$

$\begin{array}{ll}-0.127 & 0.899\end{array}$

$\begin{array}{ll}-0.135 & 0.893\end{array}$

$\begin{array}{ll}-0.082 & 0.935\end{array}$

$\begin{array}{ll}-0.118 & 0.906\end{array}$

$-0.2310 .818$

$\begin{array}{ll}-0.231 & 0.818 \\ -0.429 & 0.668\end{array}$

$\begin{array}{rr}-0.429 & 0.668 \\ 0.127 & 0.899\end{array}$

$\begin{array}{rr}0.127 & 0.899 \\ -0.286 & 0.775\end{array}$

$\begin{array}{ll}-0.021 \quad 0.984 \\ -0.220 & 0.826\end{array}$

$-0.220 \quad 0.826$

$\begin{array}{ll}-0.342 & 0.732\end{array}$

$\begin{array}{ll}-0.799 & 0.424\end{array}$

$\begin{array}{rr}-0.799 & 0.424 \\ 0.316 & 0.752\end{array}$

$\begin{array}{ll}0.316 & 0.752 \\ 0.132 & 0.895\end{array}$

$\begin{array}{ll}-0.143 & 0.887\end{array}$

$-0.141 \quad 0.888$

$\begin{array}{ll}-0.249 & 0.803\end{array}$

$\begin{array}{ll}-0.483 & 0.629\end{array}$

$\begin{array}{ll}-0.090 & 0.929\end{array}$

$\begin{array}{rr}-0.090 & 0.929 \\ 0.273 & 0.785\end{array}$

$0.071 \quad 0.943$

$\begin{array}{rr}-0.002 & 0.998\end{array}$

$\begin{array}{ll}0.555 & 0.579\end{array}$

$\begin{array}{ll}-0.153 & 0.879\end{array}$

$\begin{array}{ll}-0.255 & 0.799\end{array}$

$\begin{array}{ll}-0.025 & 0.980\end{array}$

$-0.109 \quad 0.913$

$\begin{array}{rr}-0.109 & 0.913 \\ 0.006 & 0.995\end{array}$

$-0.044 \quad 0.965$

$0.555 \quad 0.579$

Relative Multivariate Kurtosis $=0.672$

Test of Multivariate Normality for Continuous variables

skewness Kurtosis skewness and Kurtosis

Value $\mathrm{Z}$-score p-value value $\mathrm{Z}$-5core P-value chi-square p-value

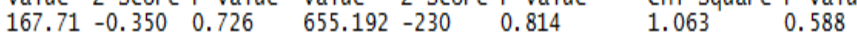

Fig 3:- Output of Data Normality Test

Figure 3 provides information that the result of normality test of the data uncover finding for univariate normality, where data can be categorized in the normal distribution if p-value and chi-square o Skewness and Kurtosis $>0.05$. Normality test of the data of this study show that the 38 indicator resulted p-value $>0.05$, skewness value $<2$, and kurtosis value $<7$. These results indicate normal distribution of data.

\section{Multicollinearity Test}

Covariance Matrix of ETA and KSI

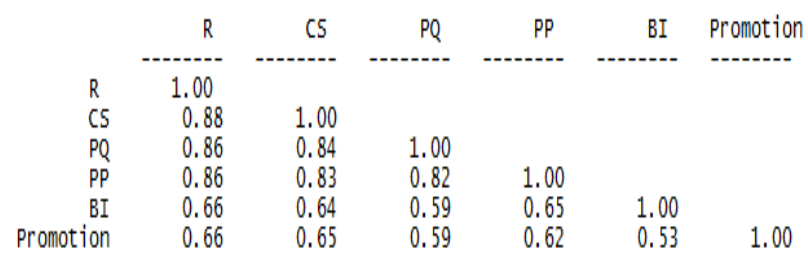

Fig 4:- Output of Multicollinearity Test
In figure 4 it can be seen the correlation between independent variables tend to be large, for the most part are above 0.5 , and none of the correlation value reach 0.9 or more. Thus, assumption of no multicollinearity has met and the analysis can continue to the next step.

\section{Model Structural Conformity Analysis}

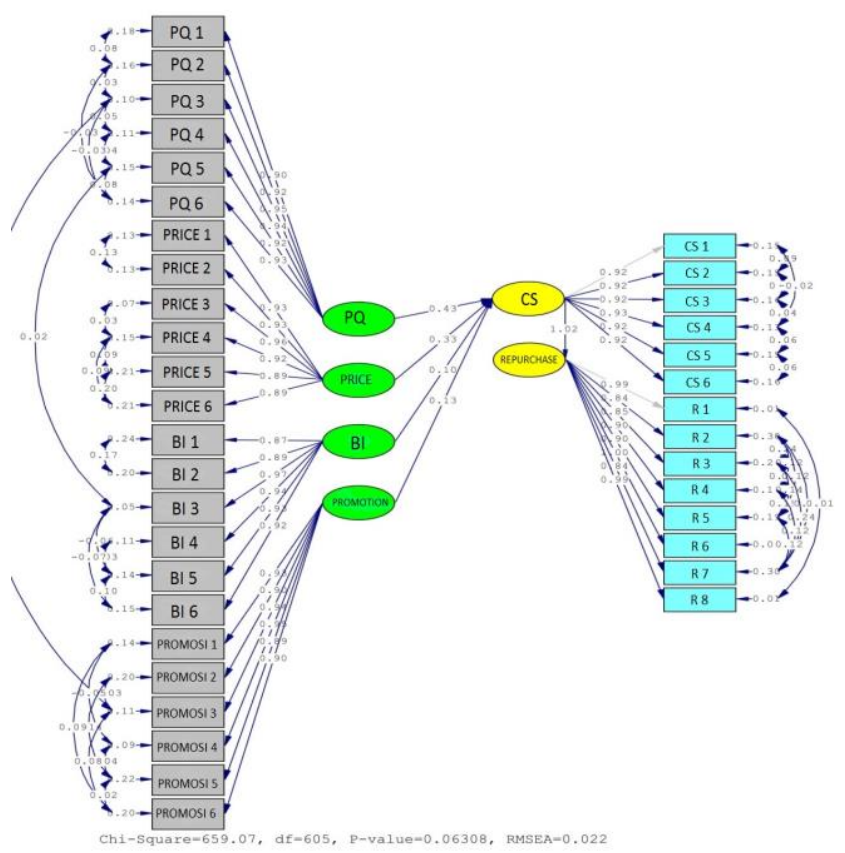

Fig 5:- Overall Variable Model

Result of hypothesis test can be seen in printed output of syntax process in the equation formula done by the researcher and also in the path diagram. Significant correlation will be marked with t-value in black color in the path diagram with value $\geq 1.96$. Insignificant correlation marked with t-value in red color in the path diagram with value lower than 1.96. Path diagram showing in Figure 4.3 provides illustration about relationship between latent variables Product Quality (x1), Product Price (X2), Brand Image (X3), Promotion (X4), Customer Satisfaction (Y1) and Repurchase Intention (Y2). In the validity and reliability test before doing model test, all variable tested has met the requirements with value $\geq 1.96$. 
ISSN No:-2456-2165

\begin{tabular}{|c|c|c|c|c|}
\hline \multirow{3}{*}{$\begin{array}{c}\text { Goodnes Of Fit Measurement } \\
\text { Normed Chi-Square }\left(\chi^{2} / \mathrm{df}\right)\end{array}$} & \multicolumn{2}{|c|}{ Conformity Scale } & \multirow{2}{*}{\multicolumn{2}{|c|}{ Measurement Result }} \\
\hline & \multirow{2}{*}{$\begin{array}{c}\text { Good Fit } \\
<2.0\end{array}$} & \multirow[t]{2}{*}{ Marginal Fit } & & \\
\hline & & & 1.089 & Fit \\
\hline Root Mean Square Error (RMSEA) & $<0.08$ & & 0.022 & Fit \\
\hline Root Mean Square Residual (RMR) & $<0.05$ & & 0.037 & Fit \\
\hline Goodness of Fit Index (GFI) & $\geq 0.90$ & $0.70<0.90$ & 0.84 & Marginal Fit \\
\hline Normal Fit Index (NFI) & $\geq 0.90$ & $0.80-<0.90$ & 0.99 & Fit \\
\hline Non-Normed Fit Index (NNFI) & $\geq 0.90$ & $0.80-<0.90$ & 1.00 & Fit \\
\hline Comparative Fit Index (CFI) & $\geq 0.90$ & $0.80-<0.90$ & 1.00 & Fit \\
\hline Increamental Fit Index (IFI) & $\geq 0.90$ & $0.80-<0.90$ & 1.00 & Fit \\
\hline Relative Fit Index (RFI) & $\geq 0.90$ & $0.80-<0.90$ & 0.99 & Fit \\
\hline
\end{tabular}

Table 7:- Goodness of Fit Full Model

Source: Lisrel Output Researcher Processsing Result (2020)

SEM analysis shows GFI value of 0.84 close to 0.90 (maginal fit), RMSEA value $0.022<0.08$ (model fit), this implies that structural model equation has met the condition of absolute fit measure which means structural model equation in this study overall have conformity with the data. In the incremental fit measure requirement, value od NNFI/TLI $1.00 \geq 0.90$ (model fit), CFI value $1.00 \geq 0.90$ (model fit), RFI value $0.99 \geq 0.90$ (model fit), NFI value $0.99 \geq 0.90$ (model fit), and IFI $1.00 \geq 0.90$ (model fit), show that structural model equation has met incremental measure fit condtion. For the parsimonious fit measure requirement, normed chi square of $1.089<2.0$ (model fit) indicate that 8 of 9 criteria confirmed the model fit, hence structural model equation has met the parsimonius fit measure which means overall structural model equation in this study have comparative conformity with the baseline model (null model).

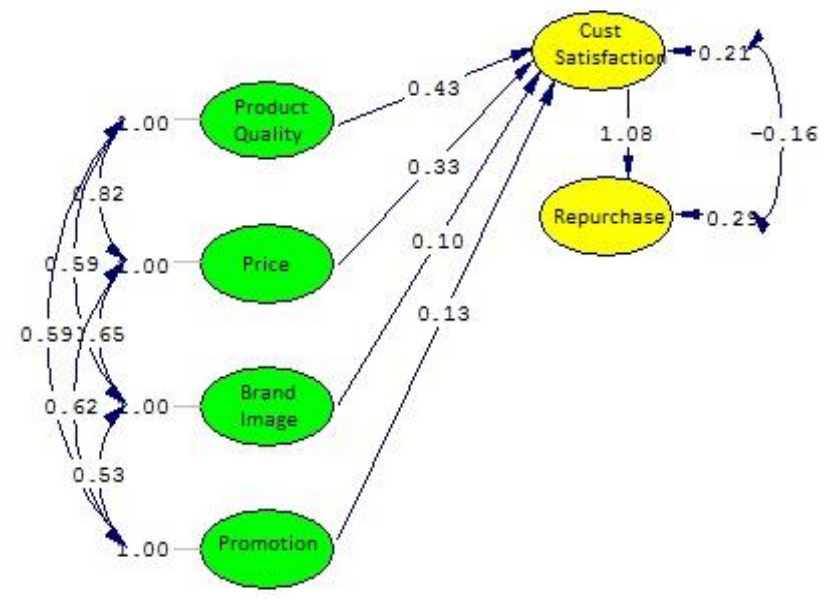

Fig 6:- Structural Model Estimates using Lisrel 8.8

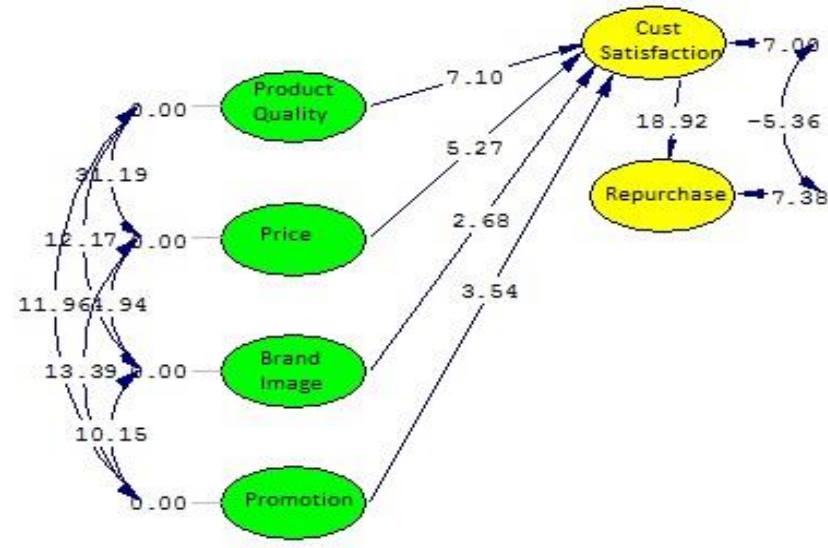

Fig 7:- Structural Model t-Value using Lisrel 8.8

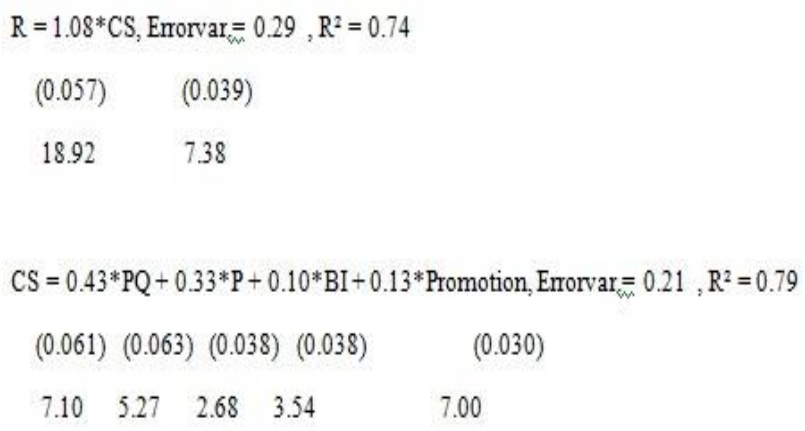

Fig 8:- Structural Model Equation Output

Figure 8 above shows that for the dependent variable of Customer Satisfaction is 0.79 meaning $79 \%$ of the existing variations can be explained by Product Quality, Product Price, Brand Image, and Promotion while the rest 0,21 or $21 \%$ is explained by other variable outside the ones used in the study. 
Product Quality, Product Price, Brand Image, and Promotion are indicated to have significant positive relation to Customer Satisfaction (Y1) with coefficient value of $0.43,0.33,0.1$, and 0.13 which are positive. Meanwhile the dependent variable Repurchase Intention is 0.74 , meaning $74 \%$ of existing variables can be explained by independent variable Customer Satisfaction and the rest 0,26 or $26 \%$ explained by other variable outside the ones used in the study. This is indicated by positive coefficient value of 1.08 .

\section{$>$ Hypothesis Testing}

Based on the result of structural model conformity test conducted previously, seven research hypothesis have been proven that there is significant correlation on confidence level of $96 \%$ with t-value > 1.96. In general, the conclusion of hypothesis testing result, indirect effect, and coefficient regression estimate can be seen in the following table.

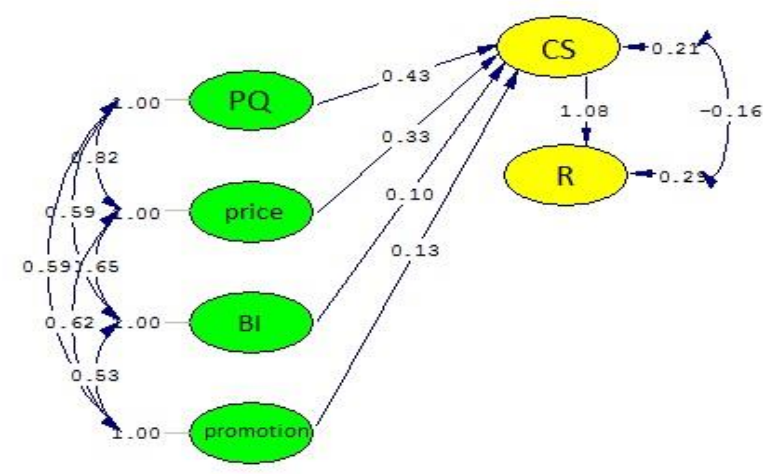

Fig 9:- Path Diagram of Structural Model Estimates Source: Primary Data Processing (2020)

\begin{tabular}{|c|c|c|c|}
\hline $\begin{array}{c}\text { Constructs } \\
\text { Correlation }\end{array}$ & Estimates & $\begin{array}{c}\text { T- } \\
\text { Values }\end{array}$ & Keterangan \\
\hline $\begin{array}{c}\text { Product Quality -> } \\
\text { Customer } \\
\text { Satisfaction }\end{array}$ & 0.43 & 7.10 & $\begin{array}{c}\text { Positive, } \\
\text { significant } \\
\text { effect }\end{array}$ \\
\hline $\begin{array}{c}\text { Product Price -> } \\
\text { Customer } \\
\text { Satisfaction }\end{array}$ & 0.33 & 5.27 & $\begin{array}{c}\text { Positive, } \\
\text { significant } \\
\text { effect }\end{array}$ \\
\hline $\begin{array}{c}\text { Brand Image -> } \\
\text { Customer } \\
\text { Satisfaction }\end{array}$ & 0.10 & 2.68 & $\begin{array}{c}\text { Positive, } \\
\text { significant } \\
\text { effect }\end{array}$ \\
\hline $\begin{array}{c}\text { Promotion -> } \\
\text { Customer } \\
\text { Satisfaction }\end{array}$ & 0.13 & 3.54 & $\begin{array}{c}\text { Positive, } \\
\text { significant } \\
\text { effect }\end{array}$ \\
\hline $\begin{array}{c}\text { Customer } \\
\text { Satisfaction -> } \\
\text { Repurchase } \\
\text { Intention }\end{array}$ & 1.08 & 18.92 & $\begin{array}{c}\text { Positive, } \\
\text { significant } \\
\text { effect }\end{array}$ \\
\hline
\end{tabular}

Table 8:- Hipothesis Testing

Source: Analysis result using Lisrel 8.8

- H1: There is positive and significant effect of Product Quality (X1) on Customer Satisfaction (Y1).

Based on table 4.8 , it is known that $\mathrm{t}$-Value $=7,10>$ 1,96. Coefficient value is positive: 0,43 , which means Product Quality variable (X1) positively affected Customer
Satisfaction variable (Y1) by 43\%. Therefore, hypothesis $\mathrm{H} 1$ in this study which state that "Product Quality (X1) has positive and significant effect on Customer Satisfaction (Y1)" is confirmed. Improving Fiesta Chicken Nugget can increase customer satisfaction by $43 \%$.

- H2: There is positive and significant effect of Product Price (X2) on Customer Satisfaction (Y1).

Based on Table 4.8, it is known that t-Value: 5,27 larger than $\mathrm{t}=1,96$. Coefficient value is positive: 0,33 , which means Product Price variable (X2) positively affected Customer Satisfaction variable (Y1) by 33\%. Therefore, hypothesis $\mathrm{H} 2$ in this study which state that "Product Price (X2) has significant effect on Customer Satisfaction (Y1)" is confirmed. Price adjustment of Fiesta Chicken Nugget can increase customer satisfaction by $43 \%$.

- H3: There is positive and significant effect of Brand Image (X3) on Customer Satisfaction (Y1).

Based on Table 4.8, it is known that t-Value: $2.68>$ 1,96. Coefficient value is positive: 0,10 , which means Brand Image variable (X3) positively affected Customer Satisfaction variable (Y1) by $33 \%$. Therefore, hypothesis $\mathrm{H} 3$ in this study which state that "Brand Image (X3) has significant effect on Customer Satisfaction (Y1)" is confirmed. Maintaining and strengthening Fiesta brand image can increase customer satisfaction by $10 \%$.

- H4: There is positive and significant effect of Promotion (X4) on Customer Satisfaction (Y1).

Based on Table 4.8, it is known that t-Value: 3.54 larger than $t=1,96$. Coefficient value is positive: 0,13 , which means Promotion variable (X4) positively affected Customer Satisfaction variable (Y1) by 13\%. Therefore, hypothesis $\mathrm{H} 4$ in this study which state that "Promotion (X4) has significant effect on Customer Satisfaction (Y1)" is confirmed. Intensfying promotion of Fiesta brand can increase customer satisfaction by $13 \%$.

- H5: There is positive and significant effect of Customer Satisfaction (Y1) on Repurchase Intention (Y2).

Based on Table 4.8, it is known that t-Value: 18,92 larger than $\mathrm{t}=1,96$. Coefficient value is positive: 1.08 which means Customer Satisfaction (Y1) positively affected Repurchase Intention variable (Y2) by $108 \%$. Therefore, hypothesis H5 in this study which state that "Customer Satisfaction (Y1) has significant effect on Repurchase Intention (Y2)” is confirmed.

\section{CONCLUSION AND RECOMENDATIONS}

\section{A. Conclusion}

Based on the research result and discussion in the previous chapters, several conclusions have drawn as follows:

$>$ Product quality variable has positive and significant effect on customer satisfaction. This means the better product quality, the customer satisfaction will increase accordingly. Product quality variabel is the variable with the most significant effect on customer satisfaction. 
$>$ Product price variable has positive and significant effect on customer satisfaction. This means the better product price, the customer satisfaction will increase accordingly.

$>$ Brand image variable has positive and significant effect on customer satisfaction. This means the better the brand image, the customer satisfaction will increase accordingly.

$>$ Promotion variable has positive and significant effect on customer satisfaction. This means with better and improved promotion, the customer satisfaction will increase accordingly.

$>$ Customer satisfaction variable has positive and significant effect on repurchase intention. This means the more satisfied the customers are, repurchase will increase accordingly.

\section{B. Recommendations}

Referring to the result of discussion analysis and the conclusions above, the following are some recommendation to complement this research result:

\section{For Company}

The SEM structural hypothesis testing analysis proved that product quality, product price, brand image, and promotion has positive and significant effect on customer satisfaction and customer satisfaction is majorly significant on repurchase intention, so the company needs to do the following suggestion:

- The manufactured product quality, which includes durability, reliability, dan perceived quality become the main variables to increase customer satisfaction.

- Product price factor particularly in the terms of affordable, quality-based, and competitive price in the customer buying power need to be maintain to keep and continue good level of customer satisfaction.

- The less significant effect of company brand image on customer satisfaction to become one of the company's focus in producing Fiesta Nugget.

\section{$>$ For the Future Research}

- Reviewing R-square test result in Chapter IV, 74\% independent varaibles (Product Quality, Price, Brand Image, and Promotion) can affect dependent variable which is Customer Satisfaction while the remaining $26 \%$ can be use in the future research, namely variables in the pre surveyin the Chapter I that are personal selling, service quality, service value, company image, location, customer experince, relationship mark, and design.

- The time limitation of research cause the sampling restric to Jakarta area. Future research can be carried out outside Jakarta with larger sample.

\section{REFERENCES}

[1]. Abdullah, Thamrin \& Francis Tantri. 2012. Manajemen Pemasaran. Jakarta: Rajawali Pers

[2]. Arbuckle, J. L., Wothke, W., 2013 Amos 22 User's Guide, Small Waters Corporation, Chicago.

[3]. Djumarno et al. 2017. The Effect of Brand Image, Product Quality, and Relationship Marketing on Customer Satisfaction and Loyalty. International Journal of Business Marketing and Management (IJBMM) Volume 2 Issue 10 November 2017, P.P.1524 ISSN: $2456-4559$

[4]. Fang. 2018. Understanding customers' satisfaction and repurchase intentions: An integration of IS success model, trust, and justice.

[5]. https://www.tib.eu/en/search/id/BLSE\%3ARN298187 149/Understanding-customers-satisfaction-andrepurchase/

[6]. Firmansyah, Anang. 2019. Pemasaran Produk dan Merek: Planning dan Strategy. Qiara Media. Jawa Timur.

[7]. Fungai. 2017. Factors Influencing Customer Repurchase Intention In The Fast Food Industry. A Case Study Of Innscor - Mutare, Zimbabwe. Business and Social Science Journal (BSSJ) Volumen 2, Issue 1, pp.120-141.

[8]. Putri dan Astuti. 2017. Faktor-Faktor Yang Mempengaruhi Kepuasan Konsumen Serta Dampaknya Terhadap Minat Beli Ulang Konsumen. Diponegoro Journal of Managemet. Volume 6 Nomor 2, Tahun 2017, Halaman 1-10.

[9]. Kotler, Philip. and Gary Armstrong. 2018. Principle Of Marketing, 17th edition. New Jersey: Pearson Prentice Hall.

[10]. Kotler, Philip and Kevin Lane Keller, 2016. Marketing Management, 15th Edition, Pearson Education,Inc.

[11]. Moslehi and Haeri. Effects of Promotion on Perceived Quality and Repurchase Intention. International Journal of Scientific Management and Development. Vol.4, No.12, pp:457-461. December 2016. ISSN: 2345-3974.

[12]. Neupane. 2015. The Effects of Brand Image on Customer Satisfaction and Loyalty Intention in Retail Supermarket Chain UK. International Journal of Social Sciences and Management Vol-2, issue-1: 926.

[13]. Rahayu et al.. 2016. Experiental Marketing Dan Pengaruhnya Terhadap Kepuasan Pelanggan Dan Minat Pembelian Ulang (Repurchase Intention) (Survei Padapelanggan Warung Coto Abdullah Daeng Sirua, Kota Makassar). Jurnal Administrasi Bisnis. Vol 35 No. 2 Tahun 2016.

[14]. Tjiptono, Fandy. 2015. Strategi Pemasaran, Edisi 4, Penerbit Andi, Yogyakarta

[15]. Zhang dan Prasongsukarn. 2017. A Relationship Study Of Price Promotion, Customer Quality Evaluation, Customer Satisfaction And Repurchase Intention: A Case Study Of Starbucks In Thailand. Proceedings of 62nd IASTEM International Conference, Bangkok, Thailand, 5th-6th July 2017. 